\title{
The effect of different levels of diet total volatile nitrogen on performance, carcass characteristics and meat total volatile nitrogen in broiler chickens
}

\author{
Farhad Fallah, Yahya Ebrahimnezhad, Naser Maheri-Sis, and Mohammad Ghasemi-Sadabadi \\ Department of Animal Science, Faculty of Animal Science and Veterinary Medicine, \\ Shabestar Branch, Islamic Azad University, Shabestar, Iran \\ Correspondence to: Yahya Ebrahimnezhad (ebrahimnezhad@gmail.com)
}

Received: 21 October 2015 - Revised: 9 April 2016 - Accepted: 15 April 2016 - Published: 26 April 2016

\begin{abstract}
This study was conducted to determine the effect of different levels of diet total volatile nitrogen (TVN) on performance, carcass characteristics and meat TVN in broiler chickens. A total of 400 one-day-old Ross 308 broiler chicks was used in this study. On the first day, male and female chicks were separated by feather sexing. In the first week, all chicks were reared together and fed with a basal diet without urea. At the beginning of the second week, the male and female chicks were weighed so that the average body weight of chicks was approximately equal in each cage. Then the male and female chicks were allocated to 25 floor pens in a completely randomized design with five treatments, five replicates and 16 chicks in each replicate (eight males and eight females) throughout the experimental period, which lasted for 42 days. Dietary treatments consisted of zero (control), 0.5, 1, 1.5 and $2 \%$ of urea in the diets. Before starting the experiment, the TVN levels in all diets were measured after adding different levels of urea, and TVN levels were 13.30, 14.95, 17.26, 23.26 and

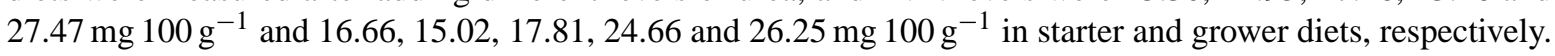
Feed intake (FI), body weight gain (BWG) and the feed conversion ratio (FCR) were measured. Carcass characteristics as well as TVN in breast meat, thigh meat and the whole carcass and in left tibia and toe ash were measured. The results showed that FI levels were significantly different between the groups at different weeks except for the second week $(P<0.05)$. The BWG significantly differed among treatments $(P<0.05)$. In the second and sixth weeks, FCR was affected by increasing TVN in the diet $(P<0.05)$. Increasing TVN in broiler diets had a significant effect on the carcass characteristics $(P<0.05)$. Increasing TVN to more than $15 \mathrm{mg} 100 \mathrm{~g} \mathrm{~g}^{-1}$ linearly reduced left tibia and toe ash $(P<0.05)$. In addition, increasing TVN in the broiler diets affected the TVN of breast meat, thigh meat and the whole carcass of broilers $(P<0.05)$. These results suggest that increasing diet

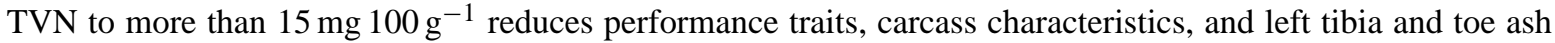
and increases the TVN amount of breast meat, thigh meat and the whole carcass.
\end{abstract}

In recent years, a lot of studies in poultry nutrition have focused on diet quality. One of the parameters for survey is total volatile nitrogen (TVN) (Ruiter, 1995). The most essential principle in the poultry industry is offering a suitable and balanced diet. As far as plant or animal proteins are concerned, attention has been paid to the fact that they have a significant effect on poultry performance. Feed and feed ingredients containing nutrients and energy resources neces- sary for growth, production and poultry health should be the standard for any species. One of the most important raw materials used in the preparation of poultry feed is fish meal, meat meal, poultry by-product meal (PBPM) and non-protein nitrogen (NPN) such as urea. Enzymatic and bacteriologic activity in these can rapidly decrease their content and quality, which causes products to be stale; some trimethylamine, dimethylamine and volatile bases are produced, which together are called TVN. Trimethylamine, dimethylamine and volatile bases are immediately spoiled, and using them in 
poultry causes toxicity. The determination of the correct amount of TVN in a diet of fish meal, as an animal protein supplement used for livestock and poultry, is of utmost importance because fish meal as a protein supplement has high digestibility and biological value (Kazemi and Balloun, 1973; Hall, 1992). In fact, TVN functions as an indicator that shows the amount of compounds containing volatile nitrogen in feed ingredients; it is thus a suitable criterion to determine the quality of the products, especially protein components, since a large part of TVN containing NPN can also be used as an indicator to determine the true quality of the protein (Ariyawansa, 2000). The nature of TVN chemicals depends on various feed ingredient sources; therefore, dimethylamine and ammonia are important parts of TVN (Ariyawansa, 2000). The TVN in meat contains ammonia along with a small amount of trimethylamine (Burks et al., 1959).

Rukchon et al. (2011) suggested that the chemical evaluation of chicken thigh meat depends on several indices like TVN, which is one of the most widely used measurements of any meat quality. Protein, as the main composition in poultry meat, is continuously broken down by microorganisms and finally produces a variety of amines including non-volatile amines, such as biogenic amines, and volatile amines, such as dimethylamine and trimethylamine and total volatile basic nitrogen (TVB-N). Consequently, these compounds can be employed as quality indicators of fresh chicken during storage. According to the Iranian Veterinary Organization's instructions regarding the control and supervision of raw meat, the maximum desirable amount of TVN in frozen chicken, turkey and ostrich meat is $20 \mathrm{mg} 100 \mathrm{~g}^{-1}$ of meat, but high levels of TVN (27 mg $100 \mathrm{~g}^{-1}$ ) have been determined in frozen meat, which is thus inedible for humans (Welch, 2000).

Egan et al. (1981) suggested that TVN was related to protein breakdown and the observed increases have been attributed to the formation of ammonia or other basic compounds due to microbial activity (Banwart, 1981). The replacement of NPN in the diet may reduce the cost of livestock and poultry diets, but it is clear that the use of nonprotein nitrogen sources has undesirable effects on poultry health (Pervaz, 1993). In recent years, the use of urea and other nitrogen compounds in poultry has been a topic of discussion. Some researchers have shown that non-ruminants can consume urea, and urea has no nutritional value for poultry (Jones and Combs, 1953; Chavez et al., 1966; Moran et al., 1967; Davis and Martindale, 1973; Kazemi and Balloun, 1973; Trakulchang and Balloun, 1975; Kobayashi et al., 1981). Some other researchers have suggested that urea be replaced by other nonessential amino acids fed to nonruminants such as poultry (March et al., 1971; Lee and Blaire, 1972; Bruckental and Nitsan, 1981; Okumura and Kino, 1984; Suciu et al., 1990).

Kagan and Balloun (1976) reported that urea as an alternative to protein cannot increase the conventional diet value of broiler chickens. Pervaz et al. (1996) observed that the use (in broiler chicken diets) of low levels of urea significantly increased the body weight gain of broiler chickens. By assessing the nutritional value of urea for broiler chickens, Prieto et al. (1978) showed that the addition of $1.39 \%$ urea to the finisher diet of broilers for the last 31 days did not have a significant effect on performance. Today, in some parts of the world, fish meal, meat meal, PBPM and NPN sources, such as urea, reduce the cost of the feed used. However, as there is little information and a lack of adequate resources at an appropriate level, this experiment was carried out to study the effects of different levels of diet TVN on performance, carcass characteristics and meat TVN in broiler chickens in order to discover what TVN levels are tolerable in a broiler diet and how to optimize these.

\section{Materials and methods}

\subsection{Animals, breeding and nutrition}

This study was conducted to determine the effects of different levels of diet TVN on performance, carcass characteristics and meat TVN in broiler chickens. A total of 400 one-day-old Ross 308 broiler chicks was used in this study. On the first day, male and female chicks were separated by feather sexing. In the first week, all chicks were reared together and fed a basal diet without urea. At the beginning of the second week, the male and female chicks were weighed so that the average body weight of chicks was approximately equal in each cage. Then the male and female chicks were allocated to 25 floor pens in a completely randomized design with five treatments, five replicates and 16 chicks in each replicate (eight males and eight females) throughout the experimental period, which lasted for 42 days. In order to create different levels of TVN in the diet, different levels of urea were used. Therefore, dietary treatments consisted of zero, $0.5,1,1.5$ and $2 \%$ urea in the diet. After the addition of urea to the diet, TVN content in the diet was measured. The amounts of TVN in the starter diets were 13.30, $14.95,17.26,23.26$ and 24.47 , and in the grower diets, they

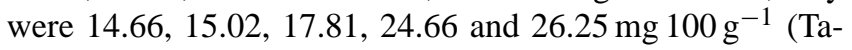
bles 1 and 2). The duration of the experimental period was 42 days. Feed and water were available ad libitum to broiler chickens. Broiler chickens were bred in floor pens, and the dimensions of each pen were $1 \mathrm{~m} \times 2 \mathrm{~m}$. All the chicks were kept under similar management conditions according to the Ross 308 strain catalogue. Animal handling and experimental procedures were performed according to the Guide for the Care and Use of Laboratory animals by the National Institutes of Health (USA) and the current laws of the Iranian government for animal care.

Nutrients for broilers were prepared based on nutritional requirements proposed by the National Research Council (1994). The basal diets were corn and soybean meal, so different percentages of urea were added to the basal diets. Urea available on the market as nitrogenous fertilizer with 
Table 1. Composition and calculated nutrient content of broilers in the starter period (7-21 days).

\begin{tabular}{|c|c|c|c|c|c|}
\hline \multirow[t]{2}{*}{ Ingredients (\%) } & \multicolumn{5}{|c|}{ Treatments } \\
\hline & Control & $\begin{array}{r}0.5 \% \\
\text { urea }\end{array}$ & $\begin{array}{r}1 \% \\
\text { urea }\end{array}$ & $\begin{array}{r}1.5 \% \\
\text { urea }\end{array}$ & $\begin{array}{r}2 \% \\
\text { urea }\end{array}$ \\
\hline Corn & 54.66 & 58.12 & 62.68 & 66.32 & 70.13 \\
\hline Soybean meal (44\% CP) & 38.00 & 33.54 & 28.78 & 24.30 & 19.73 \\
\hline Soybean oil & 3.47 & 3.39 & 2.55 & 2.35 & 2.05 \\
\hline Urea & 0.00 & 0.50 & 1.00 & 1.50 & 2.00 \\
\hline Dicalcium phosphate (DCP) & 1.50 & 1.61 & 1.66 & 1.75 & 1.87 \\
\hline $\mathrm{CaCO}_{3}$ & 1.35 & 1.34 & 1.35 & 1.34 & 1.25 \\
\hline Common salt & 0.30 & 0.30 & 0.30 & 0.30 & 0.30 \\
\hline Vitamin premix ${ }^{\mathrm{a}}$ & 0.25 & 0.25 & 0.25 & 0.25 & 0.25 \\
\hline Mineral premix ${ }^{b}$ & 0.25 & 0.25 & 0.25 & 0.25 & 0.25 \\
\hline DL-methionine & 0.12 & 0.17 & 0.20 & 0.23 & 0.25 \\
\hline L-lysine monohydrochloride & 0.11 & 0.25 & 0.43 & 0.59 & 0.78 \\
\hline L-threonine & 0.00 & 0.08 & 0.17 & 0.24 & 0.32 \\
\hline $\mathrm{K}_{2} \mathrm{SO}_{4}$ & 0.00 & 0.20 & 0.38 & 0.58 & 0.82 \\
\hline \multicolumn{6}{|l|}{ Calculated analysis } \\
\hline Metabolizable energy $\left(\mathrm{Kcal} \mathrm{kg}^{-1}\right)$ & 3000 & 3000 & 3000 & 3000 & 3000 \\
\hline Crude protein $(\%)$ & 21.56 & 21.56 & 21.56 & 21.56 & 21.56 \\
\hline Calcium $(\%)$ & 0.97 & 0.97 & 0.97 & 0.97 & 0.97 \\
\hline Available phosphorus (\%) & 0.44 & 0.44 & 0.44 & 0.44 & 0.44 \\
\hline Sodium $(\%)$ & 0.14 & 0.14 & 0.14 & 0.14 & 0.14 \\
\hline Potassium (\%) & 0.93 & 0.93 & 0.93 & 0.93 & 0.93 \\
\hline Chlorine (\%) & 0.22 & 0.22 & 0.22 & 0.22 & 0.22 \\
\hline Lysine (\%) & 1.35 & 1.35 & 1.35 & 1.35 & 1.35 \\
\hline Methionine (\%) & 0.48 & 0.48 & 0.48 & 0.48 & 0.48 \\
\hline Met + Cys (\%) & 0.84 & 0.84 & 0.82 & 0.80 & 0.77 \\
\hline Threonine $(\%)$ & 0.89 & 0.89 & 0.89 & 0.89 & 0.89 \\
\hline Tryptophan $(\%)$ & 0.31 & 0.28 & 0.25 & 0.22 & 0.19 \\
\hline TVN (mg $\left.100 \mathrm{~g}^{-1}\right)$ & 13.3 & 14.95 & 17.26 & 23.26 & 24.47 \\
\hline Cation-anion balance $\left(\right.$ meq $\left.\mathrm{kg}^{-1}\right)$ & 237.35 & 237.35 & 237.35 & 237.35 & 237.35 \\
\hline
\end{tabular}

$46 \%$ nitrogen was used in this study. The experimental diets are shown in Tables 1 and 2.

\subsection{Diet total volatile nitrogen}

Before beginning the experiment and after adding urea to diets, the TVN level was measured (AOAC, 1992). The diet was examined by the Kjeldahl method and by methods for measurement of TVN in the diet. Ten grams of each sample was obtained and placed in the Kjeldahl distillation system; then volatile nitrogen was collected in a glass balloon (containing boric acid (2\%), methyl red and bromocresol green) and titrated with sulfuric acid $(0.1 \mathrm{~N})$ for the measurement of TVN (mg $100 \mathrm{~g}^{-1}$ of diet; AOAC, 1992).

\subsection{Performance traits}

At the end of each week, feed intake (FI), body weight gain (BWG) and the feed conversion ratio (FCR) were measured. The European Production Index (EPI) for the whole period ( 7 to 42 days) of breeding was calculated using the following equation.

$$
\begin{aligned}
\mathrm{EPI}= & (\text { daily weight gain }[\mathrm{g}] \times \text { livability }[\%] / \\
& (\text { feed conversion ratio }[\mathrm{g} / \mathrm{g}]) \times 100
\end{aligned}
$$

At 42 days, four chicks (two male and two female) from each group were selected, slaughtered and dissected manually. Then relative weights, including live body weight and the weight of the eviscerated carcass, liver, heart, spleen, pancreas, intestine, bursa of Fabricius, lungs, gizzard and abdominal fat, were recorded and expressed as a percentage of 
Table 2. Composition and calculated nutrient content of broilers in the grower period (22-42 days).

\begin{tabular}{|c|c|c|c|c|c|}
\hline \multirow[t]{2}{*}{ Ingredients $(\%)$} & \multicolumn{5}{|c|}{ Treatments } \\
\hline & Control & $\begin{array}{r}0.5 \% \\
\text { urea }\end{array}$ & $\begin{array}{r}1 \% \\
\text { urea }\end{array}$ & $\begin{array}{r}1.5 \% \\
\text { urea }\end{array}$ & $\begin{array}{r}2 \% \\
\text { urea }\end{array}$ \\
\hline Corn & 59.42 & 63.5 & 67.58 & 71.78 & 75.65 \\
\hline Soybean meal (44\% CP) & 32.60 & 28 & 23.42 & 18.76 & 14.23 \\
\hline Soybean oil & 4.41 & 3.90 & 3.40 & 2.83 & 2.49 \\
\hline Urea & 0.00 & 0.50 & 1.00 & 1.50 & 2.00 \\
\hline Dicalcium phosphate (DCP) & 1.23 & 1.29 & 1.34 & 1.40 & 1.41 \\
\hline $\mathrm{CaCO}_{3}$ & 1.29 & 1.29 & 1.30 & 1.30 & 1.29 \\
\hline Common salt & 0.30 & 0.30 & 0.30 & 0.30 & 0.30 \\
\hline Vitamin premix ${ }^{a}$ & 0.25 & 0.25 & 0.25 & 0.25 & 0.25 \\
\hline Mineral premix ${ }^{\mathrm{b}}$ & 0.25 & 0.25 & 0.25 & 0.25 & 0.25 \\
\hline DL-methionine & 0.10 & 0.12 & 0.14 & 0.17 & 0.20 \\
\hline L-lysine monohydrochloride & 0.13 & 0.30 & 0.47 & 0.64 & 0.81 \\
\hline L-threonine & 0.00 & 0.08 & 0.15 & 0.23 & 0.31 \\
\hline $\mathrm{K}_{2} \mathrm{SO}_{4}$ & 0.00 & 0.20 & 0.38 & 0.57 & 0.79 \\
\hline Salinomycin & 0.02 & 0.02 & 0.02 & 0.02 & 0.02 \\
\hline \multicolumn{6}{|l|}{ Calculated analysis } \\
\hline Metabolizable energy $\left(\mathrm{Kcal} \mathrm{kg}^{-1}\right)$ & 3120 & 3120 & 3120 & 3120 & 3120 \\
\hline Crude protein $(\%)$ & 19.61 & 19.61 & 19.61 & 19.61 & 19.61 \\
\hline Calcium $(\%)$ & 0.87 & 0.87 & 0.87 & 0.87 & 0.87 \\
\hline Available phosphorus (\%) & 0.37 & 0.37 & 0.37 & 0.37 & 0.37 \\
\hline Sodium $(\%)$ & 0.14 & 0.14 & 0.14 & 0.14 & 0.14 \\
\hline Potassium $(\%)$ & 0.83 & 0.83 & 0.83 & 0.83 & 0.83 \\
\hline Chlorine $(\%)$ & 0.22 & 0.22 & 0.22 & 0.22 & 0.22 \\
\hline Lysine (\%) & 1.22 & 1.22 & 1.22 & 1.22 & 1.22 \\
\hline Methionine (\%) & 0.42 & 0.42 & 0.42 & 0.42 & 0.42 \\
\hline Met + Cys (\%) & 0.77 & 0.74 & 0.71 & 0.69 & 0.66 \\
\hline Threonine (\%) & 0.79 & 0.79 & 0.79 & 0.79 & 0.79 \\
\hline Tryptophan (\%) & 0.25 & 0.23 & 0.21 & 0.18 & 0.15 \\
\hline TVN (mg $\left.100 \mathrm{~g}^{-1}\right)$ & 14.66 & 15.02 & 17.81 & 24.66 & 26.25 \\
\hline Cation-anion balance (meq kg-1) & 211.71 & 211.71 & 211.71 & 211.71 & 211.71 \\
\hline
\end{tabular}

body weight. The chickens from each replicate (two male and two female chicks) were slaughtered separately. Samples of $20 \mathrm{~g}$ of the whole carcass, breast and thigh meat were collected, and TVN was measured using the Silva and Gloria (2002) method. Left tibia and toe samples were completely cleaned of soft tissue and meat. Then, left tibia and toe ash were determined based on the AOAC (1992) method.

\subsection{Statistical analysis}

Significant differences between mean values were separated by the general linear model (GLM) procedure of the SAS software (2003), and significant differences between treatments were identified using a Tukey range test at $P<0.05$.

\section{Results and discussion}

The effects of different levels of TVN in the diet on BWG, FI, FCR and EPI in all weeks in broiler chicken are shown in Table 3.

The results showed that through increasing the levels of TVN by adding urea to the diet, BWG decreased linearly in different weeks $(P<0.05)$. So, as TVN in the diet increased

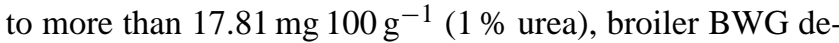
creased significantly $(P<0.05)$. The effect of FI on broiler chickens in the experimental groups was significant at different rearing weeks $(P<0.05)$, except in the first weeks $(7-$ 14 days). In addition, in other weeks, with the increase in the levels of TVN in the diet to more than $15.2 \mathrm{mg} 100 \mathrm{~g}^{-1}$ $(0.5 \%$ urea $)$, FI decreased significantly $(P<0.05)$. The effect 
Table 3. The effects of diet TVN on performance of broiler chickens (7-42 days). SEM: standard error of the mean.

\begin{tabular}{|c|c|c|c|c|c|c|c|c|}
\hline \multirow[t]{2}{*}{ Ingredient (\%) } & \multirow[t]{2}{*}{ Period } & \multicolumn{5}{|c|}{ Urea level (TVN for starter and grower period in $\mathrm{mg} 100 \mathrm{~g}^{-1}$ ) } & \multirow[b]{2}{*}{ SEM } & \multirow[b]{2}{*}{$P$ value } \\
\hline & & $\begin{array}{r}\text { Control } \\
(13.30,14.66)\end{array}$ & $\begin{array}{r}0.5 \% \text { urea } \\
(14.95,15.02)\end{array}$ & $\begin{array}{r}1 \% \text { urea } \\
(17.26,17.81)\end{array}$ & $\begin{array}{r}1.5 \% \text { urea } \\
(23.26,24.66)\end{array}$ & $\begin{array}{r}2 \% \text { urea } \\
(24.47,26.25)\end{array}$ & & \\
\hline \multicolumn{9}{|c|}{ Body weight gain (g) } \\
\hline & 7-14 days & $184.99^{\mathrm{a}}$ & $165.31^{\mathrm{ab}}$ & $164.21^{\mathrm{ab}}$ & $141.45^{\mathrm{ab}}$ & $119.06^{\mathrm{b}}$ & 8.51 & 0.0007 \\
\hline & 14-21 days & $314.06^{\mathrm{a}}$ & $292.03^{\mathrm{ab}}$ & $268.45^{\mathrm{ab}}$ & $229.84^{b}$ & $146.62^{c}$ & 11.49 & 0.0001 \\
\hline & 21-28 days & $346.40^{\mathrm{a}}$ & $342.97^{\mathrm{a}}$ & $301.95^{\mathrm{ab}}$ & $272.51^{\mathrm{ab}}$ & $220.96 b$ & 19.11 & 0.0016 \\
\hline & $28-35$ days & $488.90^{\mathrm{a}}$ & $418.30^{\mathrm{a}}$ & $440.28^{\mathrm{a}}$ & $351.40^{\mathrm{ab}}$ & $252.70^{b}$ & 26.62 & 0.0002 \\
\hline & 35-42 days & $471.71^{\mathrm{ab}}$ & $526.71^{\mathrm{a}}$ & $260.02^{c}$ & $386.02^{\mathrm{bc}}$ & $217.53^{d}$ & 18.78 & 0.0001 \\
\hline & 7-42 days & $1940.62^{\mathrm{a}}$ & $1809.32^{\mathrm{a}}$ & $1647.75^{b}$ & $1501.70^{\mathrm{b}}$ & $1060.84^{c}$ & 35.68 & 0.0001 \\
\hline \multicolumn{9}{|l|}{ Feed intake (g) } \\
\hline & 7-14 days & 295.46 & 278.43 & 306.64 & 381.78 & 374.21 & 12.30 & 0.3500 \\
\hline & 14-21 days & $470.10^{\mathrm{a}}$ & $447.82^{\mathrm{a}}$ & $395.78^{b}$ & $364.99^{c}$ & $315.11^{\mathrm{d}}$ & 5.16 & 0.0001 \\
\hline & 21-28 days & $735.21^{\mathrm{a}}$ & $698.77^{\mathrm{a}}$ & $696.00^{\mathrm{a}}$ & $578.41^{\mathrm{b}}$ & $483.18^{c}$ & 14.59 & 0.0001 \\
\hline & 28-35 days & $1041.40^{\mathrm{a}}$ & $970.76^{\mathrm{a}}$ & $983.23^{\mathrm{a}}$ & $842.81^{\mathrm{b}}$ & $697.15^{c}$ & 20.03 & 0.0001 \\
\hline & 35-42 days & $1067.41^{\mathrm{ab}}$ & $1088.20^{\mathrm{a}}$ & $853.26^{\mathrm{c}}$ & $924.06^{\mathrm{bc}}$ & $658.89^{d}$ & 25.92 & 0.0001 \\
\hline & $7-42$ days & $3544.07^{\mathrm{a}}$ & $3526.86^{\mathrm{a}}$ & $3219.40^{\mathrm{b}}$ & $3018.46^{\mathrm{b}}$ & $2420.99^{c}$ & 62.22 & 0.0001 \\
\hline \multicolumn{9}{|c|}{ Feed conversion ratio } \\
\hline & 7-14 days & $1.59^{\mathrm{b}}$ & $1.69^{\mathrm{b}}$ & $1.85^{\mathrm{ab}}$ & $2.00^{\mathrm{ab}}$ & $2.35^{\mathrm{ab}}$ & 0.11 & 0.0020 \\
\hline & 14-21 days & 1.49 & 1.53 & 1.47 & 1.58 & 2.37 & 0.23 & 0.0700 \\
\hline & 21-28 days & 2.12 & 2.07 & 2.34 & 2.11 & 2.19 & 0.12 & 0.6000 \\
\hline & $28-35$ days & 2.13 & 2.32 & 2.31 & 2.39 & 2.76 & 0.13 & 0.0400 \\
\hline & $35-42$ days & $2.26^{\mathrm{b}}$ & $2.07^{\mathrm{b}}$ & $2.38^{\mathrm{b}}$ & $2.38^{\mathrm{b}}$ & $3.03^{\mathrm{a}}$ & 0.08 & 0.0001 \\
\hline & $7-42$ days & $1.82^{\mathrm{b}}$ & $1.94^{\mathrm{b}}$ & $1.96^{\mathrm{b}}$ & $2.00^{\mathrm{ab}}$ & $2.28^{\mathrm{a}}$ & 0.05 & 0.0010 \\
\hline \multicolumn{9}{|c|}{ European Production Index } \\
\hline & $7-42$ days & $204.48^{\mathrm{a}}$ & $210.86^{\mathrm{a}}$ & $170.80^{\mathrm{b}}$ & $151.25^{\mathrm{b}}$ & $85.63^{\mathrm{c}}$ & 7.14 & 0.0001 \\
\hline
\end{tabular}

of the experimental groups was significant regarding FCR in broilers $(P<0.05)$ : with an increase in the levels of TVN in

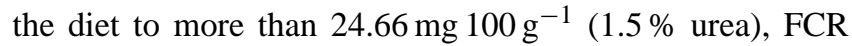
was worse at 7-14, 35-42 and 7-42 days compared with other treatments. The EPI of broiler chickens in the experimental groups decreased linearly $(P<0.05)$ with an increase

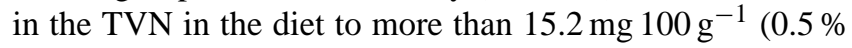
urea).

By examining the results obtained, it can be concluded that the increase in TVN in broiler chickens' diet to more

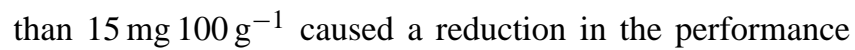
of broiler chickens. It has been reported that the use of high levels of urea in the diet decreased the performance of broiler chickens (Javed et al., 1995; Pervaz, 1993; Pervaz et al., 1994; Javed et al., 2002). However, Pervaz et al. (1994) showed that low levels of urea (less than $1 \%$ ) in the diet significantly increased the BWG of broiler chickens. March et al. (1971) reported that using 1 or $2 \%$ of urea in the diet decreased the BWG and increased FCR. In another experiment, Isikwenu (2012) stated that the use of urea in the diet decreased the performance of broiler chickens, and this may be due to reduced FI. Javed et al. (2002) reported that the use of $4 \%$ of urea in the diet does not affect FI, BWG and carcass weight significantly in the first 3 weeks compared to the control group. In addition, Shahzad et al. (2012) reported that the use of $1 \%$ of urea in the diet has no harmful effects on the performance of chickens. Trakulchang and Balloun (1975) observed that $0.43 \%$ urea in the diet did not significantly affect BWG or FI in chickens.

Sahraei et al. (2012) showed that the use of PBPM in poultry diets containing TVN at a concentration of

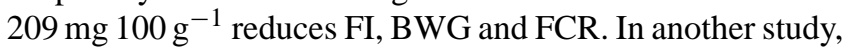
Sahraei et al. (2012) stated that the use of different levels of meat meal in broiler chicken diets decreased performance parameters. Botta et al. (1984) reported that the addition of high-level PBPM to poultry diets containing $209 \mathrm{mg} 100 \mathrm{~g}^{-1}$ TVN had a negative effect on broiler chickens; as a result, increasing losses and negative performance were observed. The negative effects of high levels of TVN in the diet on performance can be related to increased uric acid and toxic effects of uric acid in the broiler chickens (Javed et al., 1995).

Guo (1983) reported that the birds exposed to high levels of urea in their diet exhibited clinical signs of toxicity similar to those reported in large animals. In ruminants, clinical signs of toxicity were attributed to an increased blood urea level since these animals have the urease enzyme (ammoniagenerating enzyme), which converts urea to ammonia (Bartik and Piskac, 1981).

Also, Chandra et al. (1984) stated that increased nitrogen intake, as is the case in urea toxicity, may result in toxic de- 
Table 4. The effects of diet TVN on carcass characteristics of broiler chickens at 42 days of age (as percentage of live body weight). SEM: standard error of the mean.

\begin{tabular}{|c|c|c|c|c|c|c|c|c|c|c|c|}
\hline $\begin{array}{l}\text { Urea level } \\
\left(\text { TVN as mg } 100 \mathrm{~g}^{-1}\right)\end{array}$ & Gender & $\begin{array}{c}\text { Carcass yield } \\
(\%)\end{array}$ & $\begin{array}{l}\text { Liver } \\
(\%)\end{array}$ & $\begin{array}{l}\text { Abdominal fat } \\
(\%)\end{array}$ & $\begin{array}{c}\text { Gizzard } \\
(\%)\end{array}$ & $\begin{array}{c}\text { Heart } \\
(\%)\end{array}$ & $\begin{array}{c}\text { Intestine } \\
(\%)\end{array}$ & $\begin{array}{c}\text { Bursa of } \\
\text { Fabricius }(\%)\end{array}$ & $\begin{array}{l}\text { Spleen } \\
(\%)\end{array}$ & $\begin{array}{c}\text { Pancreas } \\
(\%)\end{array}$ & $\begin{array}{c}\text { Lungs } \\
(\%)\end{array}$ \\
\hline Control (14.66) & & $68.96^{\mathrm{a}}$ & $3.02^{\mathrm{a}}$ & $1.54^{\mathrm{b}}$ & $2.10^{\mathrm{a}}$ & $0.52^{\mathrm{b}}$ & $3.60^{\mathrm{ab}}$ & $0.06^{\mathrm{ab}}$ & 0.10 & $0.17^{\mathrm{b}}$ & 0.54 \\
\hline $0.5 \%(15.02)$ & & $66.59^{b}$ & $2.78^{\mathrm{b}}$ & $1.53^{\mathrm{b}}$ & $2.07^{\mathrm{a}}$ & $0.54^{\mathrm{b}}$ & $3.71^{\mathrm{a}}$ & $0.04^{\mathrm{b}}$ & 0.10 & $0.18^{\mathrm{b}}$ & 0.50 \\
\hline $1 \%(17.81)$ & & $62.24^{\mathrm{c}}$ & $2.84^{\mathrm{b}}$ & $1.61^{\mathrm{b}}$ & $2.11^{\mathrm{a}}$ & $0.53^{\mathrm{b}}$ & $3.34^{\mathrm{bc}}$ & $0.06^{\mathrm{a}}$ & 0.10 & $0.17^{\mathrm{b}}$ & 0.56 \\
\hline $1.5 \%(24.66)$ & & $53.86^{\mathrm{d}}$ & $2.94^{\mathrm{b}}$ & $1.72^{\mathrm{b}}$ & $2.23^{\mathrm{a}}$ & $0.61^{\mathrm{ab}}$ & $3.42^{\mathrm{abc}}$ & $0.07^{\mathrm{a}}$ & 0.12 & $0.22^{\mathrm{ab}}$ & 0.53 \\
\hline $2 \%(26.25)$ & & $48.38^{e}$ & $2.69^{b}$ & $2.02^{\mathrm{a}}$ & $1.62^{b}$ & $0.70^{\mathrm{a}}$ & $3.21^{\mathrm{c}}$ & $0.07^{\mathrm{a}}$ & 0.12 & $0.25^{\mathrm{a}}$ & 0.55 \\
\hline SEM & & 0.36 & 0.16 & 0.06 & 0.08 & 0.03 & 0.09 & 0.003 & 0.006 & 0.01 & 0.03 \\
\hline Female & & 60.00 & 3.05 & 1.63 & $1.94^{\mathrm{b}}$ & 0.59 & $3.36^{\mathrm{b}}$ & $0.060^{\mathrm{a}}$ & 0.10 & 0.19 & 0.53 \\
\hline Male & & 59.63 & 3.05 & 1.73 & $2.11^{\mathrm{a}}$ & 0.57 & $3.54^{\mathrm{a}}$ & $0.068^{b}$ & 0.11 & 0.20 & 0.54 \\
\hline SEM & & 0.22 & 0.10 & 0.03 & 0.05 & 0.02 & 0.05 & 0.002 & 0.004 & 0.008 & 0.02 \\
\hline Control (14.66) & Female & 69.03 & 2.97 & 1.48 & 1.96 & 0.58 & 3.46 & $0.06^{\mathrm{abc}}$ & 0.10 & 0.17 & 0.53 \\
\hline Control (14.66) & Male & 66.79 & 2.93 & 1.51 & 2.03 & 0.57 & 3.68 & $0.04^{\mathrm{d}}$ & 0.10 & 0.18 & 0.53 \\
\hline $0.5 \%(15.02)$ & Female & 62.42 & 3.09 & 1.48 & 1.97 & 0.57 & 3.19 & $0.05^{\mathrm{bcd}}$ & 0.10 & 0.16 & 0.58 \\
\hline $0.5 \%(15.02)$ & Male & 54.30 & 2.86 & 1.65 & 2.16 & 0.60 & 3.30 & $0.06^{\mathrm{bc}}$ & 0.11 & 0.21 & 0.51 \\
\hline $1 \%(17.81)$ & Female & 47.46 & 3.39 & 2.04 & 1.61 & 0.65 & 3.20 & $0.06^{\mathrm{bc}}$ & 0.12 & 0.24 & 0.51 \\
\hline $1 \%(17.81)$ & Male & 68.89 & 3.06 & 1.60 & 2.25 & 0.36 & 3.73 & $0.05^{\mathrm{cd}}$ & 0.11 & 0.17 & 0.55 \\
\hline $1.5 \%(24.66)$ & Female & 66.40 & 2.63 & 1.55 & 2.11 & 0.51 & 3.74 & $0.05^{\mathrm{cd}}$ & 0.10 & 0.18 & 0.46 \\
\hline $1.5 \%(24.66)$ & Male & 62.02 & 2.58 & 1.74 & 2.26 & 0.49 & 3.49 & $0.07^{\mathrm{ab}}$ & 0.11 & 0.19 & 0.54 \\
\hline $2 \%(26.25)$ & Female & 53.48 & 3.02 & 1.79 & 2.29 & 0.62 & 3.54 & $0.08^{\mathrm{a}}$ & 0.13 & 0.22 & 0.54 \\
\hline $2 \%(26.25)$ & Male & 47.31 & 3.98 & 2.00 & 1.63 & 0.76 & 3.22 & $0.08^{\mathrm{a}}$ & 0.12 & 0.26 & 0.59 \\
\hline \multirow[t]{2}{*}{ SEM } & & 0.16 & 0.07 & 0.027 & 0.036 & 0.016 & 0.04 & 0.001 & 0.002 & 0.005 & 0.015 \\
\hline & & & & & $P$ value & & & & & & \\
\hline Urea level & & 0.0001 & 0.0016 & 0.0001 & 0.0001 & 0.0021 & 0.0014 & 0.0001 & 0.0745 & 0.0002 & 0.7353 \\
\hline Gender & & 0.2542 & 0.9667 & 0.0640 & 0.0276 & 0.4300 & 0.0316 & 0.0144 & 0.2511 & 0.2268 & 0.8584 \\
\hline Urea level $\times$ gender & & 0.9622 & 0.1729 & 0.5010 & 0.6817 & 0.1918 & 0.7271 & 0.0383 & 0.6673 & 0.9793 & 0.5610 \\
\hline
\end{tabular}

$\mathrm{a}, \mathrm{b}, \mathrm{c}$ : means in columns with same superscript do not differ significantly $(P<0.05)$.

generative changes to various tissues. Moreover, ammonia increased in the caecum due to the action of caecal urease in urea; this ammonia may be absorbed and carried to the liver, which is thus subjected to the damaging effect of ammonia.

The different studies showed that high uric acid levels have toxic effects on broilers chickens (Shahzad et al., 2012). In a similar study, Javed et al. (1995) reported that a higher level of urea in the diet increased blood uric acid and urea levels in broilers. Therefore, high uric acid intensified liver and kidney damage. Kagan and Balloun (1976) reported that in birds, the intestinal ureolytic activity is also very low and urea is completely absorbed without a concomitant increase in blood ammonia, so that the high level of urea in the blood increased urea intoxication in chickens. Also, Nagalakashmi et al. (1999) reported that the urea concentrations were increased in the blood when the concentration of urea was increased in the diet.

The histological findings were described with reference to uric acid granulation and calcinosis. Abdou et al. (2006) reported that the high urea level in broiler chickens' diet increased uric acid (hyperuricaemia), which was probably the result of increased biosynthesis or decreased renal excretion of uric acid from the kidney.

The toxicity of urea occurs due to local and generalized effects of ammonia released in sufficient amounts. Urea- ammoniated diets may be responsible for reduced growth, feed intake and efficiency of nutrient utilization. The use of a high level of urea in the diet is one of the important nutritional factors leading to nephritis. Therefore, nephritis in poultry is caused either by nutritional imbalances or infectious agents. Different renal and biochemical changes were observed in chicks fed a urea-containing diet, including increased levels of glutamate oxaloacetate transaminase, glutamate pyruvate transaminase, uric acid and NPN in serum. Increases in blood urea and hypoglycemia and a decrease in hepatic glucose-6-phosphatase were also observed. These changes were directly correlated with the severity of nephritis and degenerative changes in various organs.

For example, histopathological changes in renal tissue may be related to increases in blood urea and uric acid levels through an increase in urea in the diet. In the presence of an increased blood urea level, abnormal catabolic activities may exist and hyperuricaemia may be increased through the catabolism of endogenous protein. Moreover, in dehydrated birds and in birds with diarrhea, it was found that the highly efficient renal tubular reabsorption resulted in increased blood urea and uric acid (Abdou et al., 2006). The results of the performance traits obtained from this experiment corresponded with the results of Abdou et al. (2006). 
Table 5. The effects of diet TVN on bone ash and the TVN value of breast, thigh and carcass of broiler chickens at 42 day of age. SEM: standard error of the mean.

\begin{tabular}{|c|c|c|c|c|c|c|}
\hline $\begin{array}{l}\text { Urea level } \\
\left(\mathrm{TVN} \text { as } \mathrm{mg} 100 \mathrm{~g}^{-1}\right)\end{array}$ & Gender & $\begin{array}{l}\text { Tibia ash } \\
(\%)\end{array}$ & $\begin{array}{l}\text { Toe ash } \\
(\%)\end{array}$ & $\begin{array}{c}\text { TVN } \\
\text { breast meat } \\
\left(\mathrm{mg} 100 \mathrm{~g}^{-1}\right)\end{array}$ & $\begin{array}{c}\text { TVN } \\
\text { thigh meat } \\
\left(\mathrm{mg} 100 \mathrm{~g}^{-1}\right)\end{array}$ & 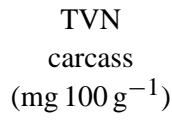 \\
\hline Control (14.66) & & $46.88^{\mathrm{a}}$ & $13.61^{\mathrm{a}}$ & $45.01^{\mathrm{c}}$ & $46.41^{\mathrm{c}}$ & $72.80^{\mathrm{d}}$ \\
\hline $0.5 \%(15.02)$ & & $45.43^{\mathrm{ab}}$ & $12.98^{\mathrm{ab}}$ & $67.41^{\mathrm{b}}$ & $61.99^{\mathrm{b}}$ & $81.85^{\mathrm{c}}$ \\
\hline $1 \%(17.81)$ & & $42.21^{b c}$ & $12.21^{b c}$ & $66.63^{\mathrm{b}}$ & $68.07^{\mathrm{a}}$ & $94.50^{\mathrm{b}}$ \\
\hline $1.5 \%(24.66)$ & & $41.02^{\mathrm{c}}$ & $11.55^{\mathrm{dc}}$ & $65.18^{\mathrm{b}}$ & $65.62^{\mathrm{ab}}$ & $97.12^{\mathrm{b}}$ \\
\hline $2 \%(26.25)$ & & $39.31^{\mathrm{c}}$ & $10.92^{\mathrm{d}}$ & $86.02^{\mathrm{a}}$ & $69.24^{\mathrm{a}}$ & $111.78^{\mathrm{a}}$ \\
\hline SEM & & 0.90 & 0.21 & 1.59 & 1.43 & 1.12 \\
\hline Female & & 42.77 & 12.24 & 66.43 & 62.85 & 91.54 \\
\hline Male & & 43.16 & 12.26 & 65.68 & 61.69 & 91.68 \\
\hline SEM & & 0.57 & 0.13 & 1.008 & 0.3726 & 0.71 \\
\hline Control (14.66) & Female & 45.60 & 13.44 & 44.45 & 46.55 & $72.01^{\mathrm{f}}$ \\
\hline Control (14.66) & Male & 46.46 & 13.25 & 65.22 & 61.86 & $73.58^{\mathrm{f}}$ \\
\hline $0.5 \%(15.02)$ & Female & 41.98 & 12.22 & 67.70 & 67.55 & $85.48^{\mathrm{de}}$ \\
\hline $0.5 \%(15.02)$ & Male & 41.32 & 11.71 & 65.80 & 66.32 & $78.22^{\mathrm{ef}}$ \\
\hline $1 \%(17.81)$ & Female & 38.52 & 11.59 & 84.17 & 71.96 & $95.37^{\mathrm{cd}}$ \\
\hline $1 \%(17.81)$ & Male & 48.16 & 13.77 & 45.58 & 46.28 & $93.62^{\mathrm{cd}}$ \\
\hline $1.5 \%(24.66)$ & Female & 44.41 & 12.71 & 64.83 & 62.12 & $98.35^{\mathrm{bc}}$ \\
\hline $1.5 \%(24.66)$ & Male & 42.44 & 12.19 & 65.53 & 68.60 & $95.90^{\mathrm{cd}}$ \\
\hline $2 \%(26.25)$ & Female & 40.71 & 11.38 & 64.57 & 64.92 & $107.18^{\mathrm{ab}}$ \\
\hline $2 \%(26.25)$ & Male & 40.10 & 11.26 & 87.87 & 66.53 & $116.37^{\mathrm{a}}$ \\
\hline \multirow[t]{2}{*}{ SEM } & & 0.40 & 0.09 & 0.71 & 0.64 & 1.59 \\
\hline & & & & $P$ value & & \\
\hline Urea level & & 0.0001 & 0.0001 & 0.0001 & 0.0001 & 0.0001 \\
\hline Gender & & 0.9047 & 0.9047 & 0.6017 & 0.3726 & 0.8890 \\
\hline Urea level $\times$ gender & & 0.2764 & 0.2764 & 0.3586 & 0.5397 & 0.0001 \\
\hline
\end{tabular}

a, b, c: means in columns with same superscript do not differ significantly $(P<0.05)$.

The effects of different levels of TVN in the diet on carcass characteristics of broiler chickens are shown in Table 4.

Results showed that increased levels of TVN in the diet linearly reduced the percentage of carcass yield as compared with the control group $(P<0.05)$. In addition, the result of this experiment showed that the use of $2 \%$ urea in the diet (TVN at a concentration of $26.25 \mathrm{mg} 100 \mathrm{~g}^{-1}$ of diet) increased the relative weight of abdominal fat, heart and pancreas compared to other treatments, while the level of TVN in the diet decreased the relative weight of the liver, gizzard and intestine in broiler chickens $(P<0.05)$. Adding $0.5 \%$ urea

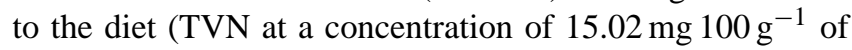
diet) reduced the relative weight of the bursa of Fabricius compared to other treatments $(P<0.05)$. The use of different levels of TVN in the diet had no significant effect on the relative weight of the spleen and lungs $(P<0.05)$.

In this experiment, it seems that the reduction in carcass yield in relation to the loss of body weight is due to the decreased FI as a result of the toxic effects of uric acid. Shahzad et al. (2012) reported that the use of $1 \%$ urea in the diet did not have a significant effect on carcass yield, liver, kidney, heart, spleen, lungs, gizzard, intestine, pancreas and bursa of Fabricius in broiler chickens. The use of high levels of urea $(4 \%)$ in diets reduced carcass yield and lowered intestine weight (Shahzad et al. 2012).

Javed et al. (2002) stated that the relative weight of carcass yield, gizzard, liver, kidney and bursa of Fabricius decreased with the addition of $4 \%$ of urea in the diet compared to the control group. Javed et al. (1995) reported that live body weight, carcass yield and relative weight of the intestine was decreased through the use of high levels of urea. Isikwenu (2012) indicated that the use of high levels of urea reduced the relative weight of carcass yield, heart, spleen, liver and gizzard in broiler chickens. In this experiment, the relative weight of the liver reduced significantly with increased levels of urea. This relative loss of liver weight can be caused by uric acid toxicity and destructive changes in the liver. $\mathrm{Ab}-$ dou et al. (2006) and Shahzad et al. (2012) stated that destructive changes were observed in liver tissue due to high levels of urea in broiler chickens.

In this experiment, the pancreas weight increased with the addition of $2 \%$ of urea to the diet. In different cases, Wight 
et al. (1986) reported that the use of urea in the diet does not have any effects on the weight of the pancreas. It seems that an increase in the percentage of abdominal fat might be due to probable amino acid imbalances in diets containing high levels of increased nitrogen. In a similar case, Sahraei et al. (2012) reported that the abdominal fat percentage of the chicks at 46 days increased as the level of TVN increased in the experimental diet, but in contrast to this finding, Bruckental and Nitsan (1981) indicated an abdominal fat decrease with an increase of urea in the diet of broiler chickens.

The effects of diet TVN on bone ash and the TVN value of breast, thigh and the carcass of broiler chickens at 42 days of age is shown in Table 5.

Results showed increased levels of TVN in the diet, higher

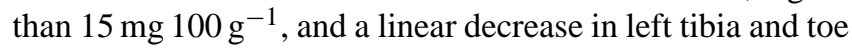
ash $(P<0.05)$. A reduction in left tibia and toe ash can be due to several factors, including the following:

a. a decrease in FI with a diet containing urea as a result of a decrease in the minerals needed for bone formation and obtained via the diet.

b. consumption of urea in the diet, effecting increased intestinal $\mathrm{pH}$ and thus reducing the absorption of minerals in bone formation.

c. an acid-base imbalance in the body and increased renal excretion of minerals needed for bone formation due to kidney damage and due to the increase in uric acid in the blood.

d. a disorder affecting the formation of the active form of vitamin $\mathrm{D}$ in the kidneys due to kidney tissue damage and a reduction in the absorption of calcium and phosphorus from the intestine.

Lierz (2003) and Al-Ankari (2006) concluded that the use of urea in a diet caused kidney damage, also causing changes in the metabolism of calcium and phosphorus in the body and thereby decreasing bone ash. Guo (1983) reported that the use of $1.5-2 \%$ of urea in the diet caused leg weakness in laying hens.

Additional levels of urea in broiler diets increased TVN in the meat of breast, thigh and the whole carcass compared to the control group $(P<0.05)$. However, minimum and maximum TVN content in the meat of breast, thigh and the whole carcass was 45.1 and $86.02,46.41$ and $69.24,72.80$ and

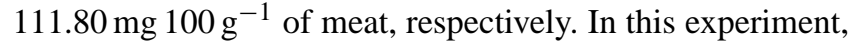
as the level of urea in the diet increased, TVN content in the breast meat, the thigh meat and the whole carcass linearly increased $(P<0.05)$.

This increase in TVN may be due to the decomposition of urea and the conversion of ammonia by intestinal microorganisms and absorption from the intestinal wall, which leads to increased levels of TVN in the meat.

Banwart et al. (1981) reported that an increase in TVN content in the meat may increase the production of ammonia and/or other nitrogenous compounds due to microbial activity in the gut. Egan et al. (1981) reported that an increase in TVN percentage in meat is related to protein breakdown.

\section{Summary}

It can be concluded from this study that the increase in

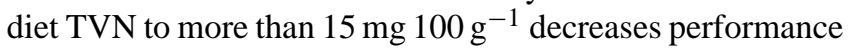
traits, carcass characteristics, and left tibia and toe ash and increases the amount of the meat of breast, thigh and the whole carcass.

Author contributions. Yahya Ebrahimnezhad designed and coordinated the experiment and prepared the manuscript. Farhad Fallah and Mohammad Ghasemi-Sadabadi carried out the experiment and helped to prepare the manuscript. Naser Maheri-Sis participated in the design of the study and helped to modify the manuscript.

Acknowledgements. This article is part of an MSc thesis by Farhad Fallah (with $20 \%$ of the data from a thesis by Mohammad Ghasemi-Sadabadi) in Animal Science, Islamic Azad University of Shabestar Branch (thesis supervisor: Yahya Ebrahimnezhad). The authors would like to thank all staff of Islamic Azad University, Shabestar Branch, for providing the necessary facilities for carrying out this research. Thanks also to Farid Tofigh Nia (neurologist) for his kind support of this study.

Edited by: M. Mielenz

Reviewed by: two anonymous referees

\section{References}

Abdou, K. A., Mubarak, M. and Sharkawy, A. A.: Toxopathological effects induced by urea in broiler chicks, Bs. Vet. Med. J., 16, 75-84, available at: https://www.researchgate. net/publication/247096715_222_Toxo-pathological_effects_ induced_by_urea_in_broiler_chicks (last access: 2013), 2006.

Al-Ankari, A. R. S.: Association between serum biochemistry of leghorn chickens and changes in renal tissues induced by high calcium and high urea diets, Int. J. Poultry Sci., 5, 992-995, 2006.

AOAC: Official methods of analysis (15th Edn.), Association of Official Analytical Chemists Inc., Arlington, VA, USA, 1992.

Ariyawansa, S.: The evaluation of functional properties of fish meal. United Nations University, Fisheries Training Programme, Project Final, Sri Lanka, 1-25, 2000.

Banwart, G. J.: Basic food microbiology, Avi Publishing Company Inc., Westport, CT, USA, 1981.

Bartik, M. and Piskac, A.: Veterinary Toxicology, Elsevier Scientific Publishing Company, Amsterdam, the Netherlands, Oxford, UK and New York, USA, 1981.

Botta, J. R., Lauder, J. T., and Jewer, M. A.: Effect of methodology on total volatile basic nitrogen ( $\mathrm{Tvb}-\mathrm{N})$ determination as an index of quality of fresh Atlantic cod (Gadus-Morhua), J. Food Sci., 49, 734-736, 1984. 
Bruckental, I. and Nitsan, Z.: Effect of urea growth, food utilization and body composition of chicks, Brit. Poultry Sci., 22, 115-121, 1981.

Burks, R. E., Baker, E. B., Clark, P., Esslinger, J., and Lacey, J. C.: Irradiation effects in meat-detection of amines produced on irradiation of beef, J. Agr. Food Chem., 7, 778-782, 1959.

Chandra, M., Singh, B., Soni, G. L., and Ahuja, S. P.: Renal and biochemical changes produced in broilers by high-protein, highcalcium, urea-containing, and vitamin A deficient diets, Avian Dis., 28, 1-11, 1984.

Chavez, R., Thomas, J. M., and Ried, B. L.: The utilization of nonprotein nitrogen by laying hens, Poultry Sci., 45, 547-553, 1966.

Davis, R. H. and Martindale, C. H.: The performance of laying hens fed on rearing and laying diets containing urea, Brit. Poultry Sci., 14, 153-160, 1973.

Egan, H., Kirk, R. S., and Sawyer, R.: Pearson's chemical analysis of foods, 8th Edn., Churchill Livingstone, Edinburgh, UK, 1981.

Guo, X. D.: Preliminary observation on urea poisoning in chickens, Chinese J. Vet. Med., 9, 36-37, 1983.

Hall, G. M.: Fish processing technology, in: Fishery byproducts, edited by: Ockerman, H. W., VCH publishers, New York, USA, 155-192, 1992.

Isikwenu, J. O.: Hematological, organs and performance response of cockerel chicks fed urea-treated and fermented brewer's dried grains diets as replacement for groundnut cake, Am. J. Food Nutr., 2, 1-6, 2012.

Javed, M. T., Pervaz, S., Sabri, M. A., Khan, H. A., Chatha, Z. A., and Younis, M.: Studies on body weight, gross pathology and some serum enzymes of urea induced toxicity in broiler chicks, Pak. Vet. J., 15, 109-112, 1995.

Javed, M. T., Sarwar, M. A., Kausar, R., and Ahmad, I.: Effects of feeding different levels of formalin (37\% formaldehyde) and urea on broiler health and performance, Vet. Arhiv, 72, 285-302, 2002.

Jones, H. L. and Combs, G. F.: Effect of aureomycin HCL on the utilization of inorganic nitrogen by the chick, Poultry Sci., 32, 873-875, 1953.

Kagan, A. and Balloun, S. L.: Urea and aspartic acid supplementation in broiler diets, Brit. Poultry Sci., 17, 403-413, 1976.

Kazemi, R. and Balloun, S. L.: Urea and diammonium citrate for laying hens, Poultry Sci., 52, 44-50, 1973.

Kobayashi, S., Koike, H., and Itoh, H.: Effects of dietary urea on nitrogen excretion in cockerels, Japanese Poultry Sci., 18, 7885, 1981 (in Japanese).

Lee, D. J. W. and Blaire, R.: Effects on chick growth of adding various non-protein nitrogen sources or dried autoclaved poultry manure to diets containing crystalline essential amino acids, Brit. Poultry Sci., 13, 243-249, 1972.

Lierz, M.: Avian renal disease: pathogenesis, diagnosis, and therapy, Vet. Clin. N. Am. Exotic Am. Pract., 6, 29-55, 2003.

March, B. E., Biely, J., Claggett, F. G., and Tarr, H. L. A.: Dogfish meals as supplements for poultry rations, Poultry Sci., 50, 10721076, 1971.

Moran, E. T., Summers, J. D., and Pepper, W. F.: Effect of nonprotein nitrogen supplementation of low protein rations on laying hen performance with a note on essential amino acid requirements, Poultry Sci., 46, 1134-1144, 1967.

Nagalakashmi, D., Sastry, V. R., Katiyar, R. C., Agrawal, D. K., and Verman, S. V.: Performance of broiler chicks fed on diets containing urea ammoniated neam (Azadirachta indica) kernel cake, Brit. Poultry Sci., 40, 77-83, 1999.

National Research Council: Nutrient requirements of poultry, 9th edition, National Academy Press, Washington, DC, USA, 1994.

Okumura, J. and Kino, K.: Growth promoting effect of dietary urea and diammonium citrate in the chick, Japanese Poultry Sci., 21, 49-56, 1984.

Pervaz, S.: Haemotological and enzymological studies of urea induced toxicity in broiler chicks, MSc (Hons.) Thesis, Department Veterinary Pathology University of Agriculture, Faisalabad, Pakistan, 1993.

Pervaz, S., Javed, M. T., and Pervaiz, S.: Studies on feed consumption, feed conversion, and live body weight and clinical signs in urea induced toxicity in broiler chicks, Singapore Vet. J., 17, 5157, 1994.

Pervaz, S., Javed, M. T., Sabri, M. A., and Pervaz, S.: Haematological and biochemical findings in broilers feed different levels of urea, Pak. Vet. J., 16, 75-77, 1996.

Prieto, C., Sanz, R., Fonolla, J., and Aguilera, J.: Nutritive use by broilers of a diet supplemented with urea, Rev. Nutr. Anim., 15, 75-85, 1978.

Ruiter, A.: Fish and fishery products composition, nutritive properties and stability, in: Fish meal and fish oil-not only by-products, edited by: Schmidtdorff, W., 347-376, 1995.

Rukchon, C. H., Trevanich, S., Jinkarn, T., and Suppakul, P.: Volatile compounds as quality indicators of fresh chicken and possible application in intelligent packaging, The 12th. Proc. ASean Food Conference, 16-18 June 2011, BITEC Bangna, Bangkok, Thailand, 2011.

Sahraei, M., Ghanbari, A., and Lootfollahian, H.: Effects of inclusion of poultry slaughter house by product meals in diet on performance, serum uric acid and carcass traits of broilers, Global Veterinaria, 8, 270-275, 2012.

SAS Institute: SAS User's Guide, Version 9.1 edn., SAS Inst. Inc., Cary, NC, USA, 2003.

Shahzad, N. M., Javed, M. T., Shabir, S., Irfan, M., and Hussain, R.: Effects of feeding urea and copper sulphate in different combinations on live body weight, carcass weight, percent weight to body weight of different organs and histopathological tissue changes in broilers, Exp. Toxicol. Pathol., 64, 141-147, 2012.

Silva, C. M. G. and Gloria, M. B. A.: Bioactive amines in chicken breast and thigh after slaughter and during storage at $4 \pm 1^{\circ} \mathrm{C}$ and in chicken-based meat products, Food Chem., 78, 241-248, 2002.

Suciu, I., Miclea, V., Tai, I., and Lozone, D.: effects of replacing part of the protein in the diet with urea, in the presence of volcanic tuff zeolite, on the performance of broiler chickens, Buletinul Institutului Agronomic Cluj-Napoca, Zootehnie şi Medicină Veterinară, 44, 13-18, 1990.

Trakulchang, N. and Balloum, S. L.: Non-protein nitrogen for growing chickens, Poultry Sci., 54, 591-594, 1975.

Welch, I.: Herding among security analysts, J. Financ. Economet., 58, 369-396, 2000.

Wight, P. A. L., Dewar, W. A., and Saunderson, C. L.: Zinc toxicity in the fowl: ultra-structural pathology and relationship to selenium lead and copper, Avian Pathol., 15, 23-28, 1986. 